\title{
FORUM
}

\section{Insect-Plant Interactions: New Pathways to a Better Comprehension of Ecological Communities in Neotropical Savannas}

\author{
Kleber Del-Claro, Helena M Torezan-Silingardi \\ Instituto de Biologia, Univ. Federal de Uberlândia, C. postal 593, 38400-902, Uberlândia, MG; \\ delclaro@ufu.br; hmtsilingardi@yahoo.com.br \\ Edited by Og de Souza - UFV \\ Neotropical Entomology 38(2):159-164 (2009)
}

Interações Inseto-Planta: Novos Caminhos para a Melhor Compreensão das Comunidades Ecológicas nas Savanas Neotropicais

\begin{abstract}
RESUMO - Os mecanismos causais que moldam e estruturam as comunidades ecológicas estão entre os mais importantes temas da ecologia. O estudo das interações inseto-planta nas redes tróficas é apontado como básico para alavancar nossos conhecimentos no assunto. Os cerrados (savana tropical), embora extremamente diversos e distribuídos em uma área superior a $20 \%$ do território brasileiro, com ricos exemplos de interações multitróficas, são pouco explorados em termos de biodiversidade interativa. Aqui, esse ecossistema é sugerido como possuidor de bons modelos para o estudo das interações insetoplanta, cuja compreensão pode lançar uma nova luz na teoria das comunidades ecológicas. Três sistemas distintos: plantas com nectários extraflorais ou herbívoros trofobiontes e a fauna de formigas associadas; herbívoros florais-predadores-polinizadores; e planta-engenheiros das florestas e a fauna associada, irão servir de exemplo para ilustrar esses novos e promissores caminhos de investigação científica no cerrado. O objetivo principal desse breve texto é instigar jovens pesquisadores, principalmente entomologistas, a iniciarem estudos de campo mais elaborados, incluindo manipulações experimentais em sistemas multitróficos, para explorar de modo interativo a estrutura que mantém preservadas as comunidades das savanas neotropicais.
\end{abstract}

PALAVRAS-CHAVE: cerrado, comunidade, interação ecológica, herbivoria

\begin{abstract}
The causal mechanisms shaping and structuring ecological communities are among the most important themes in ecology. The study of insect-plant interactions in trophic nets is pointed out as basic to improve our knowledge on this issue. The cerrado tropical savanna, although extremely diverse, distributed in more than $20 \%$ of the Brazilian territory and filled up with rich examples of multitrophic interactions, is underexplored in terms of biodiversity interaction. Here, this ecosystem is suggested as valuable to the study of insect-plant interactions whose understanding can throw a new light at the ecological communities' theory. Three distinct systems: extrafloral nectary plants or trophobiont herbivores and the associated ant fauna; floral herbivores-predators-pollinators; and plantsforest engineers and associated fauna, will serve as examples to illustrate promising new pathways in cerrado. The aim of this brief text is to instigate young researchers, mainly entomologists, to initiate more elaborated field work, including experimental manipulations in multitrophic systems, to explore in an interactive way the structure that maintain preserved viable communities in the Neotropical savanna.
\end{abstract}

KEY WORDS: cerrado, community, ecological interaction, herbivory

\section{The Biodiversity of Plant-Animal Interactions}

The comprehension of the causal mechanisms that shape the structure of ecological communities through trophic interactions is one of the most important themes in ecology (e.g. Paine 1980, Polis 1999, Borer et al 2005 and references therein). A basic tool used to study how communities are established and organized is the investigation of the direct trophic relationships influencing species interactions and biodiversity in natural systems (Del-Claro 2004, Thompson 2005). In a community, species may be linked directly or indirectly through resources and consumption (Polis \& Winemiller 1996). More than $90 \%$ of the fixed energy in terrestrial systems is processed autotrophically by plants 
(the remaining is done by algae and bacteria), and almost all terrestrial fauna depends on this production (Price 2002a).

Nowadays, it is assumed that $22 \%$ of all species in the biota are composed by plants, $26 \%$ by herbivorous insects and $31 \%$ by carnivorous or saprophagous, that obtain energy on their primary consumers and producers (Strong et al 1984). In systems involving three trophic levels, such as plants, herbivores and predators, a trophic cascade describes the positive top-down effects of the third trophic level on the biomass, richness or composition of the producer species (Hairston et al 1960, Polis et al 2000). Predators frequently cause significant impact on density, spatial distribution and diversity of herbivore assemblages, thereby altering the patterns and levels of herbivory in plant communities (e.g. Del-Claro et al 1996, Romero \& Vasconcellos-Neto 2004). These consequences are also observed for pollinator guilds influenced by predators (Dukas \& Morse 2003).

On the other hand, plant quality and herbivores action (bottom-up effects) on plant architecture, distribution and population dynamics can also produce great impact on the associated fauna (e.g. Thompson 1994). Considering these whole of information ones must agree that biodiversity should be viewed and evaluated also in ways to embrace the inherent richness of plant-animal interactions, including the ecological role of species, interaction types and their results, structure of trophic web, selection pressures, habitat heterogeneity and geographical variation (Price 2002b). Biodiversity should be understood in an interactive way, searching for the richness of biotic relationships in a particular environment, as it is suggested as a keystone to maintain preserved natural communities (Thompson 2005). In this sense, biodiversity is beyond species richness, it comprises all the ecological conditions that support the interactions that maintain the vigor of species richness in a definite time and space interval.

\section{The Cerrado Tropical Savannas}

The cerrado biome of tropical South America covers about 2 million $\mathrm{km}^{2}$, an area similar of the one occupied by the Western Europe, representing ca. 22\% of the land surface of Brazil. It extends from the southern borders of the Amazonian forest to outlying areas in the southern states of São Paulo and Paraná. The distribution of the cerrado biome is highly coincident with the plateau of central Brazil, which divides three of the largest South American water basins: those of the Amazon, Plate/Paraguay, and São Francisco rivers (see Oliveira-Filho \& Ratter 2002, to a complete characterization). The cerrado is the most diverse tropical savanna in fauna and flora, and its landscape presents also great variation with several vegetation physiognomy, from opened areas of large fields up to a close and dry forest with trees reaching 10 to $12 \mathrm{~m}$ tall (Oliveira-Filho \& Ratter 2002). Despite this great importance in area and diversity, research on this vegetation type is mainly driven to exploit new manners of use, especially for agriculture or pasture. Studies on interspecific ecology represent less than $8 \%$ of the general research conducted in the cerrado (e.g. Oliveira \& Marquis 2002).
Characterized by two contrasting seasons, the rainy (November to May) and the dry season (June to October), when fire events can occur, the cerrado represents an extraordinary opportunity to the study of biodiversity interaction and its impacts on community ecology, especially if focused on plant-insect relationships. The main reasons are that: a) it covers the major part of central Brazil, where preserved areas are relatively easy to access and some of the most developed academic institutions in the country are inside or in the borders of the cerrado distribution; b) the cerrado strict sense, the commonest vegetal physiognomy, has shrubs and trees between 1-3 m tall, which facilitates experimental manipulation. Other positive fact is that several abundant plant species present an aggregate distribution; c) the insect fauna is diverse, which also results in a diversity of interactions; d) there are good plant collections in the public educational institutions of central and southeast Brazil; e) the Brazilian scientific support agencies have specific programs to attend the improvement of research in central western Brazil, giving support to young doctors to establish a research line in this field work.

\section{Insect-Plant Interactions: Suggestive New Pathways in Cerrado}

In the last twenty years ecological publications having the cerrado as background increased significantly (e.g. Oliveira \& Marquis 2002, Oliveira \& Freitas 2004, and references therein). However, considering insect-plant interactions and its implications in food webs and multitrophic relationships, the number of papers is still now almost insignificantly when compared to temperate areas (e.g. Oliveira 1997, Leal \& Oliveira 1998, Del-Claro \& Oliveira 2000, Fernandes et al 2005, Freymann et al 2008, Rosa et al 2008). Indeed, only one study (Oliveira \& Del-Claro 2005) deeply examined the whole natural history and ecology of a plant-arthropod interaction (ants-membracid-plant-herbivores) with its implications to all related members. Nevertheless, several other systems could be successfully explored (e.g. termitesplants-associated fauna; galls-plants-parasitoids) and here, we will point three of these clear "opportunities" that should be known and evaluated by young entomologists: (a) extrafloral nectary plants (EFNs) or trophobiont herbivores and the associated ant fauna; (b) floral herbivores-predators and plant pollinators; and (c) plants-forest engineers and associated fauna.

\section{Efns Bearing Plants/Trophobiont Herbivores and Ants}

EFNs are nectar-producing glands that are not involved with pollination, but instead attract ants and other arthropods in a wide range of plants (Koptur 1992). These structures have been present in Angiosperm at least since the Oligocene (Pemberton 1992). Several authors have demonstrated that associations between ants and EFNs are beneficial for the plants in Neotropical savannas (e.g. Del-Claro et al 1996, 
Oliveira 1997, Korndörfer \& Del-Claro 2006, Rico-Gray $\&$ Oliveira 2007). Ants protect plants against the action of herbivores, which they prey upon or drive away (e.g. RicoGray \& Oliveira 2007, and references therein). In a similar way trophobiont herbivores, like hemipterans (e.g. Del-Claro 2004) and lepidopteran larvae (Oliveira \& Freitas 2004), can attract and feed ants with rich sugary secretions receiving protection against natural enemies and indirectly benefiting the host plant (e.g. Del-Claro \& Oliveira 2000, Oliveira \& Del-Claro 2005).

Systems like these are common in cerrado, presenting a great overlap of interacting species. Oliveira \& Del-Claro (2005) showed that only one plant-hemipteran-ant association can put together in the same scenario 21 ant species, more than 15 distinct spider species, three other herbivores and also hemipteran predators and parasitoids. Additionally, these authors showed that such relationships can vary depending on biotic and seasonal changes. Because organisms interact not only directly, but also indirectly with other organisms in nature, indirect effects (like facilitation or inhibition) are important forces forming ecological communities (Ohgushi 2008). However, studies investigating these indirect effects are rare in tropical savannas, suggesting questions like: would insect herbivore-induced changes in EFNs bearing plants greatly increase the bottom-up effects of plant genotypic or phenotipic variation, thus influencing the abundance of herbivores, predators and parasitoids? How important is the presence of ants in these systems facilitating or reducing the occurrence of other organisms? Is there any plant response to the trophobiont herbivore and does it reflect on the outcome of the associations? In terms of net interactions, what is the impact of ant-plant-herbivore systems to cerrado biodiversity as a whole? Besides these and others more elaborate questions, simple questions also remain to be answered in this interesting line of investigation. For example, the benefits received by ants in ant-plant or in ant-trophobiont herbivores relationships are assumed as true, but rarely tested and, in fact, never proved.

\section{Floral Herbivores-Predators and Plant Pollinators}

Since the last two decades of the twenty century the international literature on plant-herbivore associations in cerrado biome increased significantly in number and quality, contributing to general comparisons between tropical and temperate systems (e.g. Dyer et al 2007). For example, the ecology of termites and its multitrophic relationships has been an issue of a crescent number of excellent papers (e.g. Gontijo \& Domingos 1991, DeSouza et al 2003, Constantino 2005, Freymann et al 2008). However, studies in interspecific ecology done in cerrado were centered, in its major part, only in leaf herbivory and limited its contribution to two trophic levels: producer and consumer.

An important plant part has been consistently forgotten in plant-herbivore interactions in cerrado, the reproductive module, the flower. Florivory, which includes damage to the reproductive (gynoecium and androecium) and not reproductive structures (sepals and petals) of a flower or a floral bud, may reduce pollen dispersal and seed production by disrupting the mutualistic relationship between a flowering plant and its animal pollinators (Leavitt \& Robertson 2006). Interactions among pollinators and their predators also need to be observed (Dukas \& Morse 2003). Long-term studies considering the associated floral-herbivore fauna to a particular plant or species group in cerrado are inexistent or are still unpublished because they were research topics of a recent thesis (e.g. Torezan-Silingardi 2007). These systems are particularly important to community ecology and herbivory due to the fact that numerous studies, in other world ecosystems, have shown many interesting consequences. Florivory directly decreases the number of perfect floral buds and flowers in a plant (Karban \& Strauss 1993, Canela \& Sazima 2003), sometimes causing the production of smaller flowers (Fraze \& Marquis 1994), and reduces visual/olfactory cues to pollinators (Krupnick \& Weis 1999, Krupnick et al 1999). Consequently, the feminine and masculine reproductive functions are negatively affected (Strauss 1997), with decreased pollen flux and fructification (Torezan-Silingardi \& Del-Claro 1998, Mothershead \& Marquis 2000, Salomão et al 2006).

In the Neotropical savanna, Torezan-Silingardi (2007) performed a real full natural history study on a trophic web based on florivory. This author simultaneously studied six Malpighiaceae species and compared plant phenology, pollinators, floral herbivores and their predators and parasitoids, added to the fruit production and seasonal variation (two years). Results revealed 328 distinct species of insect floral visitors distributed in 59 families (10 orders), being 69 species (Apoidea) possible pollinators or oil/polen users, 172 floral (bud, flower or initial fruit) herbivores and 91 predators or parasitoids. However, what most call the attention in this study is not only the enormous diversity, but the fact that great part of these species move between plant species (the net present great connectivity) according to the variation of plant phenology (especially the production of reproductive structures), showing a clear interconnection in the community. Studies like this are basic to a better comprehension of causal mechanisms that shape and structure the ecological communities, making this model another important cerrado "opportunity" to be explored.

\section{Plant-Forest Engineers and Associated Fauna}

Plant-feeding insects that construct shelters on their food plants provide ample opportunities for examining the impacts of allogenic ecosystem engineering on nature's most diverse groups of organisms, the arthropods. These plantengineers (sensu Lawton 1983, Marquis \& Lill 2007) build shelters that serve as habitats for a variety of plant-dwelling arthropods that exploit a range of available resources within these constructs (e.g. Marquis \& Lill 2007). In evaluating the importance of shelter buildings in structuring arthropod communities, the abundance, size and spatial distribution of shelter-builders and their constructs within plant canopies are likely to be more important than their species richness (Marquis \& Lill 2007). Therefore, these systems also 
represent a good opportunity to investigate structure and links between guilds.

Although widespread in almost all ecological systems, the ecology of plant-feeding insects that build shelters on their food plants, for example leaf-rollers, was also neglected in studies in Neotropical savannas. However, the available literature presents high quality information serving as the basis for the development of new studies (e.g. Diniz \& Morais 1997, Costa \& Varanda 2002). These systems, although well studied in other parts of world, still have a series of untouched questions to help on understanding community structure. For example, the quality of plant tissue seems to be important in leaf occupancy not only by leaf-rollers, but also by other associated herbivores (Costa \& Varanda 2002, Marquis \& Lill 2007). So, how do age, quality and size of the leaf impact the development of leaf-roller and associated fauna in the cerrado? How does the development of leaf-roller and associated fauna reflect in a multitrophic structure? Do leaf-rollers change the habitat (due to plant architecture modification) producing a more suitable environment to arthropods? One should consider that the cerrado is a dry and hot environment in the major part of the year, and saving moisture or protecting against direct sunlight exposure make the shelters produced by forest-engineers a disputed microhabitat. This microhabitat modification can, in fact, affect the interaction diversity associated to the host plant? The presence of leaf-rollers can affect host plant fitness? How and when?

\section{Conclusions}

The Brazilian tropical savanna presents all the conditions required to the development of more advanced research, to test and evaluate the impact of the entomofauna on the mechanisms that structure ecological communities. The "opportunities" here presented and briefly discussed intended to exemplify how variable can be the possibilities of study related to insect-plant interactions in this ecosystem and how it can contribute to the general ecological theory.

Multitrophic studies on insect-plant interactions, if well designed and performed in distinct geographical areas, can produce relevant information to a better understanding on the ways that interspecific interactions can shape the organization of communities, revealing links between species and ecosystems. But it does not end at this point, as to the present examples or to other similar ones (e.g. leaf-cut ants and plants - Leal \& Oliveira 1998; herbivores (galls) and inflorescences - Fernandes et al 2005; Termites, dung beetles and plants - Rosa et al 2008, Freymann et al 2008). Community ecology needs additional answers to two main questions: how conservative are multitrophic interactions in terms of space and time? Are the outcomes of associations conditional, depending on phylogeographical or phylogenetical variation of the associated species? Answers to these questions will contribute to the knowledge of the coevolutionary processes involved in the development and maintenance of trophic relationships and to provide human beings with the required information to develop well structured conservation strategies to maintain viable the diversity and complexity of natural communities.

\section{Acknowledgements}

Thanks to Everton Tizo-Pedroso, Denise Lange and one anonymous referee for comments on the early version of the manuscript. K Del-Claro thanks CNPq $(\mathrm{PQ}$ - research grant and fellowship) and Fapemig (research grant). H M TorezanSilingardi thanks Fapemig (Pos-doctoral fellowship) and Instituto de Biologia, Universidade Federal de Uberlândia for logistic support.

\section{References}

Borer E T, Seabloom E W, Shurin J B, Anderson K E, Blanchette C A, Broitman B, Cooper S D, Halpern B S (2005) What determines the strength of a trophic cascade? Ecology 86: 528-537.

Canela M B F, Sazima M (2003) Florivory by the crab Armases angustipes influences hummingbird visits to Aechmea pectinata (Bromeliaceae). Biotropica 35: 289-294.

Constantino R (2005) Padrões de diversidade e endemismo de térmitas no bioma cerrado, p. 320-333. In Scariot A, SousaSilva J C, Felfili J M (orgs) Cerrado: ecologia, biodiversidade e conservação. Ministério do Meio Ambiente, Brasília, 487p.

Costa AA, Varanda E M (2002) Building of leaf shelters by Stenoma scitiorella Walter (Lepidoptera: Elachistidae): Manipulation of host plant quality. Neotrop Entomol 31: 537-540.

Del-Claro K (2004) Mulitrophic relationships, conditional mutualisms, and the study of interaction biodiversity in tropical savannas. Neotrop Entomol 33: 665-672.

Del-Claro K, Berto V, Réu W (1996) Herbivore deterrence by visiting ants cerrado vegetation. J Trop Ecol 12: 887-892.

Del-Claro K, Oliveira P S (2000) Conditional outcomes in a neotropical treehopper-ant association: temporal and speciesspecific effects. Oecologia 124: 156-165.

DeSouza O, Albuquerque L, Pinto L, Tonello V, Reis Jr R (2003) Effects of fire on termite generic richness in a savanna-like ecosystem 'cerrado' of Central Brazil. Sociobiology 42: 639-649.

Diniz I R, Morais H C (1997) Lepidopteran caterpillars fauna of cerrado host plants. Biodiv Conserv 6: 817-836.

Dukas R, Morse D H (2003) Crab spiders affect flower visitation by bees. Oikos 101: 157-163.

Dyer L A, Singer M S, Lill J T, Stireman J O, Gentry G L, Marquis R J, Ricklefs R E, Greeney H F, Wagner D L, Morais H C, Diniz I R, Kursar T A, Coley P D (2007) Host specificity of Lepidoptera in tropical and temperate forests. Nature 448: 696-670.

Fernandes G W, Fagundes M, Greco M K B, Barbeitos M C, Santos J C (2005) Ants and their effects on an insect herbivore community associated with the inflorescences of Byrsonima crassifolia (Linnaeus) H.B.K. (Malpighiaceae). Rev Bras Entomol 49: 264-269.

Frazze J E, Marquis R J (1994) Environmental contribution to floral trait variation in Chamaecrista fasciculata (Fabaceae: Caesalpinoideae). Am J Bot 81: 206-215. 
Freymann B P, Buitenwerf R, DeSouza O, Olff H (2008) The importance of termites (Isoptera) for the recycling of herbivore dung in tropical ecosystems: a review. Eur J Entomol 105: 165-173.

Gontijo T A, Domingos D J (1991) Guild distribution of some termites from cerrado vegetation in South-East Brazil. J Trop Ecol 7: 523-529.

Hairston N G, Smith F E, Slobodkin L B (1960) Community structure, population control, and competition. Am Nat 94: 421-425.

Karban R, Strauss S Y (1993) Effects of herbivores on growth and reproduction of their perennial host, Erigeron glaucus. Ecology 71: 39-46.

Koptur S (1992) Extrafloral nectar-mediated interactions between insects and plants, p.81-129. In Bernays E (ed) Insect-plant interactions, CRC Press, 487p.

Korndörfer A P, Del-Claro K (2006) Ant defense versus induced defense in Lafoensia pacari (Lythraceae), a myrmecophilous tree of the Brazilian cerrado. Biotropica 38: 786-788.

Krupnik G A, Weis A E (1999) The effect of floral herbivory on male and female reproductive success in Isomeris arborea. Ecology 80: 135-149.

Krupnik G A, Weis A E, Campbell D R (1999) The consequences of floral herbivory for pollinator service to Isomeris arborea. Ecology 80: 125-134.

Lawton J H (1983) Plant architecture and the diversity of phytophagous insetcs. Annu Rev Entomol 28: 23-39.

Leal I R, Oliveira P S (1998) Interactions between fungus-growing ants (Attini), fruits and seeds in cerrado vegetation in Southeast Brazil. Biotropica 30: 170-178.

Leavitt H, Robertson I C (2006) Petal herbivory by chrysomelid beetles ( Phyllotreta sp.) is detrimental to pollination and seed production in Lepidium papilliferum (Brassicaceae). Ecol Entomol 31: 657-660.

Mothershead K, Marquis R J (2000) Fitness impacts of herbivory through indirect effects on plant-pollinator interactions in Oenothera macrocarpa. Ecology 8: 30-40.

Marquis R J, Lill J T (2007) Effects of arthropods as physical ecosystem engineers on plant-based trophic interaction webs, p.246-274. In Ohgushi T, Craig T P, Price P W (eds) Indirect interaction webs: nontrophic linkages through induced plant traits. Cambridge University Press, 475p.

Ohgushi T (2008) Herbivore-induced indirect interaction webs on terrestrial plants: the importance of non-trophic, indirect, and facilitative interactions. Entomol Exp Appl 128: 217-229.

Oliveira P S (1997) The ecological function of extrafloral nectarines: herbivore deterrence by visiting ants and reproductive output in Caryocar brasiliense (Caryocaraceae). Funt Ecol 11: 323-330.

Oliveira P S, Del-Claro K (2005) Multitrophic interactions in a Neotropical savanna: ant-hemiptera systems, associated insect herbivores, and a host plant, p.414-438. In Burslem D F R P,
Pinard M A, Hartley S E (eds) Biotic interactions in the tropics, Cambridge University Press, Cambridge, 564p.

Oliveira P S, Freitas A V L (2004) Ant-plant-herbivore interactions in the Neotropical cerrado savanna. Naturwisenschaten 91: 557-570.

Oliveira P S, Marquis R J (2002) The cerrados of Brazil: Ecology and natural history of a Neotropical savanna. Columbia University Press, New York, 398p.

Oliveira-Filho A T, Ratter J A (2002) Vegetation physiognomies and woody flora of the cerrado biome, p.91-120. In Oliveira P S, Marquis R J (eds) The cerrados of Brazil: ecology and natural history of a neotropical savanna. Columbia University Press, New York, 398p.

Paine R T (1980) Food webs: linkage, interaction strength and community infrastructure. J Anim Ecol 49: 667-685.

Pemberton R W (1992) Fossil extrafloral nectarines, evidence for the ant-guard antiherbivore defense in an Oligocene Populus. Amer J Bot 79: 1242-1246.

Polis G A (1999) Why are parts of the world green? Multiple factors control productivity and the distribution of biomass. Oikos 86: 3-15.

Polis G A, Sears A L W, Huxel G R, Strong D R, Maron J (2000) When is a trophic cascade a trophic cascade? Tree 15:473-475.

Polis G A, Winemiller K O (1996) Food webs. Integration of patterns and dynamics. Chapman and Hall, New York, 548p.

Price P W (2002a) Species interactions and the evolution of biodiversity, p.3-25. In Herrera C M, Pellmyr O (eds) Plant animal interactions, Blackwell Science Ltd, Oxford, 313p.

Price P W (2002b) Macroevolutionary theory on macroecological patterns. Cambridge University Press, Cambridge, 291p.

Price P W, Diniz I R, Morais H C, Marques E S A (1995) The abundance of insect herbivore species in the tropics: high local richness of rare species. Biotropica 27: 468-478.

Rico-Gray V, Oliveira P S (2007) The ecology and evolution of antplant interactions. The University of Chicago Press, Chicago, $331 \mathrm{p}$.

Romero G Q, Vasconcellos-Neto J (2004) Beneficial effects of lower-dwelling predators on their host plant. Ecology, 85: 446-457.

Rosa C S, Marins A, DeSouza O (2008) Interactions between beetle larvae and their termite hosts (Coleoptera; Isoptera, Nasutitermitinae). Sociobiology 51: 191-197.

Salomão A T, Martins LF, Ribeiro R S, Romero G Q (2006) Effects of patch size and floral herbivory on seed set in Trichogoniopsis adenantha (Asteraceae) in Southeastern Brazil. Biotropica 38: 272-275.

Strauss S Y (1997) Floral characters link herbivores, pollinators, and plant fitness. Ecology 78: 1640-1645.

Strong Jr R, Lawton J H, Southwood T R E (1984) Insects on plants: community patterns and mechanisms. Blackwell Scientific Publications, Oxford, 437p. 
Thompson J N (1994) The coevolutionary process. The University of Chicago Press, Chicago, 376p.

Thompson J N (2005) The geographic mosaic of coevolution. University of Chicago Press, Chicago, 443p.

Torezan-Silingardi H M (2007) A influência dos herbívoros florais, dos polinizadores e das características fenológicas sobre a frutificação de espécies da família Malpighiaceae em um cerrado de Minas Gerais. Tese de doutorado, USP- FFCLRP, Ribeirão Preto, 172p.

Torezan-Silingardi H M, Del-Claro K (1998) Behavior of visitors and reproductive biology of Campomanesia pubescens (Myrtacea) in cerrado vegetation. Rev Cien Cult 50: 280-283.

Received 24/X/08. Accepted 31/III/09. 